Author: JC Knobel

THE BALD AND GOLDEN EAGLE PROTECTION ACT, SPECIESBASED LEGAL PROTECTION AND THE DANGER OF MISIDENTIFICATION

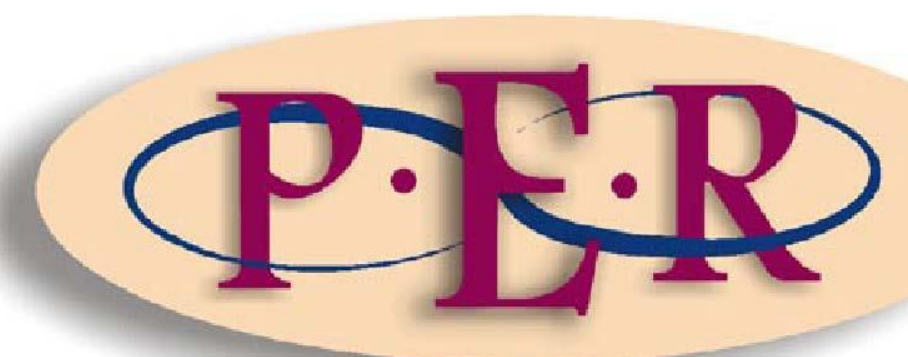

2015 VOLUME 18 No 7 


\section{THE BALD AND GOLDEN EAGLE PROTECTION ACT, SPECIES-BASED LEGAL PROTECTION AND THE DANGER OF MISIDENTIFICATION}

JC Knobel*

\section{Introduction: species, environmental law and the danger of misidentification}

Species are important in environmental law. Legislation bestowing protection on various components of biodiversity typically contains lists of species, divided into different categories such as "Endangered", "Threatened"; "Protected" and so forth. ${ }^{1}$ Such categories of species are then made subject to varying degrees of legal protection. Exceptions exist where species are not mentioned by name, but are rather included in defined groups. For instance, the relevant legislation may provide that all indigenous vertebrate animals in a given area of jurisdiction are legally protected. ${ }^{2}$ Nevertheless, species-based legal protection remains a pervasive feature of biodiversity legislation. Species-based legal protection is the norm rather than the exception in South Africa too, and national and provincial laws typically incorporate lists of species. ${ }^{3}$

Johann C Knobel. BLC LLB (University of Pretoria) LLD (University of South Africa). Professor of Private Law, University of South Africa. Email: knobejc@unisa.ac.za. Assistance by the following institutions and persons is gratefully acknowledged: financial assistance by the National Research Foundation of South Africa; assistance with the locating of source materials by Travis Rosenberry of the Research Library of the Peregrine Fund; insightful discussions with Richard T Watson PhD, Vice-president of the Peregrine Fund and André Botha, Manager of the Birds of Prey Programme of the Endangered Wildlife Trust; and valuable comments by two anonymous reviewers. The views expressed in this contribution are those of the author, unless the contrary is stated.

1 The Council Directive 2009/147/EC (30 November 2009) on the Conservation of Wild Birds (Codified Version) [2010] OJ L 20/7 (European Union); the Endangered Species Act of 1973 (16 USC 1531) (USA); and the Environment Protection and Biodiversity Conservation Act 1999 (Cth) read with the Environment Protection and Biodiversity Conservation Act List of Threatened Fauna and the Environment Protection and Biodiversity Conservation Regulations 2000 (Cth) (Australia) are notable examples of such legislation from different jurisdictions.

2 Eg s 14 Wildlife Conservation Act 1950 (Western Australia).

3 An example from South African national legislation is the National Environmental Management: Biodiversity Act 10 of 2004 (NEMBA), read with the Threatened or Protected Species Regulations, 2007 (TOPS Regulations). Examples from South African provincial legislation are: Nature and Environmental Conservation Ordinance 19 of 1974 (Western Cape, Eastern Cape); Northern Cape Nature Conservation Act 9 of 2009 (Northern Cape); Nature Conservation Ordinance 8 of 1969 (Free State); Nature Conservation Ordinance 15 of 1974; Kwa-Zulu Nature Conservation Act 29 of 1992 (KwaZulu-Natal); Nature Conservation Ordinance 12 of 1983 (Gauteng, Northwest 
The practice of basing legal protection on the concept of a "species" is not entirely free from difficulties. At a most fundamental level, scientists are not agreed on what a species is. ${ }^{4}$ Competing species concepts have been proposed, of which the Biological Species Concept and the Phylogenetic Species Concept are the most influential. ${ }^{5}$ Depending upon which species concept scientists favour, they may give different answers to the question of whether a given population of plants or animals constitutes a species or perhaps only a race or subspecies. In addition, the classification of populations into species can be fluid and can change over time. Advances in science enable researchers to gain new insights in respect of the boundaries between different species. ${ }^{6} \mathrm{~A}$ population that has been considered to constitute a single species may be "split" into two or more independent species, while two or more populations that have been considered to constitute two or more species may be "lumped" into a single species. That this fluidity presents a challenge to those persons tasked with the protection of biodiversity, whether they find themselves in government or in a non-governmental organisation, should speak for itself. $^{7}$

In addition to these considerations, it is important to note that environmental laws can define "species" to mean something different from the meaning given to the term by scientists in the natural sciences. For instance, a given law may define "species" to include subspecies and distinct populations within a species. ${ }^{8}$ Therefore, even though the species may be the unit of choice for the purpose of legal

Province); Bophuthatswana Nature Conservation Act 3 of 1973 (Northwest Province, Free State) Mpumalanga Nature Conservation Act 10 of 1998 (Mpumalanga); Limpopo Environmental Management Act 7 of 2003 (Limpopo).

$4 \quad$ See Birkhead, Wimpenny and Montgomerie Ten Thousand Birds 75-115; Del Hoyo and Collar Birds of the World 20-30; Dickinson and Remsen Checklist xiv; Liebesman and Petersen Endangered Species Deskbook 14 n 23.

5 Del Hoyo and Collar Birds of the World 20-30; Dickinson and Remsen Checklist xiv.

6 Del Hoyo and Collar Birds of the World 24-30; Dickinson and Remsen Checklist xi.

7 See Del Hoyo and Collar Birds of the World 19-20.

$8 \mathrm{Eg}$ in the USA Endangered Species Act of 1973 (16 USC 1531-1544) s 1532 (16): "The term 'species' includes any subspecies of fish or wildlife or plants, and any distinct population segment of any species of vertebrate fish or wildlife which interbreeds when mature." See further Committee on Scientific Issues in the Endangered Species Act et al Science and the Endangered Species Act 5-6; Liebesman and Petersen Endangered Species Deskbook 14; Ruhl "Listing Endangered and Threatened Species" 17. 
protection, the concept as used in a specific law may well differ from the concept of a species in the natural sciences.

This contribution will focus on an entirely different difficulty inherent in the practice of basing legal protection on species lists. It will proceed from the assumption that, in a given case, there is substantial consensus and clarity on the above-mentioned aspects, which might otherwise have introduced uncertainty. Now the following scenario presents itself for consideration: A certain species receives legal protection under a statute that is in force in a jurisdiction where that species occurs. The statute inter alia makes provision for penal sanctions if members of the species are killed, captured, or traded. Another species is unprotected (or is subject to a much lower degree of legal protection) and its distribution range overlaps with that of the protected species. The two species are sufficiently similar in appearance that a danger of misidentification exists. To an experienced scientist examining museum or herbarium specimens in the hand, the difference between the two species may be apparent, but other persons may find it difficult to tell them apart. Even that same scientist may find it difficult to correctly identify members of the two species when observing them in the field rather than in a museum or herbarium. Note that, in this scenario, neither competing species concepts nor new scientific advances are introducing uncertainty as to whether the two species really are two species. There is consensus about their status as species and there is consensus about the diagnostic features by which they are identified. The problem is created by the fact that those diagnostic features are sufficiently subtle that members of the two species may be misidentified in the field.

A person now encounters a member of the protected species, mistakes it for a member of the unprotected species, and kills it. If legislation that provides for a criminal sanction does not specify that liability is strict or may be based on negligence, fault in the form of intention will usually be a requisite. ${ }^{9}$ Because the

9 On the general position in South African law, see Glazewski Environmental Law 26.18; Snyman Criminal Law 240; further Burns and Kidd "Administrative Law" 252; Kidd Environmental Law 277. For a topical American example, see the Bald and Golden Eagle Protection Act of 1940 (16 2607 
person in the scenario sketched above was under the mistaken impression that he or she had killed a member of an unprotected species, no intention is present, ${ }^{10}$ and unless the legislation protecting the protected species makes provision for strict ${ }^{11}$ or negligence-based liability, ${ }^{12}$ the person may not be convicted. Thus the legal protection bestowed upon the protected species is rendered ineffective. A situation can also be envisaged where a person encounters a member of a protected species, is uncertain about its identity but foresees the possibility that it could be a protected species, and kills it nonetheless. In this case the person had intention in the form of dolus eventualis (at least in South African law), ${ }^{13}$ and may in theory be prosecuted successfully. However, unless the accused is a person of rare honesty, the prosecution will be faced with an insurmountable evidentiary challenge in respect of the accused's state of mind, and may hence be unable to prove the required fault element, and for practical purposes the legal provision may be unenforceable. The implication should be clear that a repetition of such incidents has the potential to make the enforcement of the legal protection of the protected species highly problematic.

The danger of the misidentification of species may be of relevance in respect of the legal protection of all biodiversity, but the focus of this contribution is on birds of prey, or raptors. ${ }^{14}$ It is well known in ornithological circles that the accurate identification of raptor species often presents particular challenges, even to experienced ornithologists. A profusion of guide books dealing with raptor identification testifies to this. ${ }^{15}$ Some authors even group raptors into "species-pairs",

USC 668) s 668. However, see Bates Environmental Law in Australia 793 on Australian environmental law.

10 Snyman Criminal Law 187, 197-198.

11 Snyman Criminal Law 236-241.

12 Snyman Criminal Law 240.

13 Snyman Criminal Law 178-184.

14 The word "raptor" is sometimes used as synonym for "bird of prey", and sometimes to denote only diurnal birds of prey, thus excluding owls. See Kemp "What is a Raptor?" 14-31. In this contribution, "bird of prey" and "raptor" are used interchangeably.

15 Notable examples from different parts of the world include Clark and Schmitt Raptors of Europe; Debus Birds of Prey of Australia; Dunne, Sibley and Sutton Hawks in Flight, Ferguson-Lees and Christie Raptors of the World (2005); Kemp and Kemp Birds of Prey, Naoroji Birds of Prey of the Indian Subcontinent, Oberprieler Raptor Guide of Southern Africa; Porter et al Flight 2608 
that is, two species that may easily be confused with each other, in an attempt better to highlight the subtle features by which those species may be differentiated from each other. ${ }^{16}$ The predatory feeding habits of raptors often bring them into conflict, whether perceived or real, with human interests. Many raptor species have suffered serious declines and many of these species are in need of protection, legal and otherwise. Therefore a situation arises where, on the one hand, many raptor species are in dire need of legal protection, but, on the other hand, some persons wish to kill raptors; ${ }^{17}$ and neither the persons who wish to do the killing nor, in many instances, the persons involved in the enforcement of protective legislation can always accurately differentiate between species that are protected and those that are unprotected or have a lower degree of protection bestowed upon them. ${ }^{18}$

This particular stumbling-block in the path to the comprehensive and effective legal protection of raptors will be the focus of this contribution. In the United States of America a simple and effective solution to this particular dilemma has been implemented by federal legislation dealing with the conservation status of two American eagle species. The American solution will be subjected to critical reflection here. As an outcome of this exercise, thoughts will be offered on the suitability of this American solution for implementation in South African law, for the benefit of South African raptor populations.

Identification of European Raptors, Steyn Birds of Prey of Southern Africa; Wheeler Raptors of Eastern North America; Wheeler Raptors of Western North America.

16 For a recent Australian example, see Debus Birds of Prey of Australia 59-71.

17 Burnham "Raptors and People" 170 et seq; Katzner and Tingay "Eagle Diversity, Ecology and Conservation" 1-2.

18 See eg Bildstein "History of Raptor Conservation" 16, describing raptor persecution in North America at a time before comprehensive legal protection was given to raptors, but when people had begun to differentiate between so-called "good" and "bad" raptors, depending on whether the raptors were thought to be beneficial or harmful to human interests: "Poultry-, game-, and bird-eating hawks, in particular, were heavily persecuted in early-20 $20^{\text {th }}$-century North America. Compounding the problem was the fact that many shooters were often unable or unwilling to distinguish the 'bad' or destructive hawks from the 'good' or 'beneficial hawks', putting all birds of prey at risk." 


\section{Two eagle species and American federal legislation}

\subsection{The Bald Eagle and American federal legislation}

The Bald Eagle ${ }^{19}$ is a big raptor species that is indigenous to the North American continent. It is a striking and well-known species and has been chosen as a national symbol of the USA. Historically the Bald Eagle had a wide distribution in North America and was not considered to be a rare bird, but Bald Eagle populations declined from the mid to late 1800 's. Declining numbers of waterfowl and shorebirds upon which the eagles preyed, direct persecution of the eagles, and habitat destruction were thought to be the causes of the decline in Bald Eagle populations. ${ }^{20}$

The federal legislature intervened and passed an Act with the sole aim of bestowing legal protection on this one single species, the Bald Eagle. The Bald Eagle Protection $A c t^{21}$ came into effect in 1940. Originally the provisions of the Act did not apply in Alaska, where the state still paid bounties for the destruction of the Bald Eagle to protect salmon stocks. However, this exemption was revoked in $1952 .{ }^{22}$ In its current form, the Act provides that:

Whoever, within the United States or any place subject to the jurisdiction thereof, without being permitted to do so as hereinafter provided, shall knowingly, or with wanton disregard for the consequences of his act take, possess, sell, purchase, barter, offer to sell, purchase or barter, transport, export or import, at any time or in any manner, any bald eagle commonly known as the American eagle ... alive or

19 Haliaeetus leucocephalus. Scientific names in this contribution follow the Dickinson and Remsen Checklist unless otherwise noted. For details on the biology and conservation status of the Bald Eagle, see BirdLife International $2015 \mathrm{http}: / /$ www.birdlife.org/datazone/speciesfactsheet. php?id=3365; Del Hoyo, Elliot and Sargatal Handbook of the Birds of the World 122-123; Ferguson-Lees and Christie Raptors of the World (2001) 400-402 (note that this is the original work published in 2001; another publication with the same title and written by the same authors, published in 2005, deals mostly with the identification of raptors and does not supply comprehensive biological detail); Global Raptor Information Network 2015 http://www.globalraptors.org/grin/SpeciesResults.asp?specID=8270; $\quad$ IUCN 2014 http://www.iucnredlist.org/details/full/22695144/0; Johnsgard Hawks, Eagles and Falcons of North America 142-152.

20 Bildstein "History of Raptor Conservation" 7-12; Noecker "Revisions" 143; Tucker Return of the Bald Eagle 57-65.

21 The Bald Eagle Protection Act of 1940 (16 USC 668). Currently, after amendments, the Act is known as the Bald and Golden Eagle Protection Act of 1940 (16 USC 668-668d). See in general Bean and Rowland Evolution of National Wildlife Law 93-102; Doub Endangered Species Act 88$91 ;$

22 Noecker "Revisions" 143; Tucker Return of the Bald Eagle 60. 
dead, or any part, nest, or egg thereof ..., or whoever violates any permit or regulation issued pursuant to this Act, shall be fined not more than $\$ 5,000$ or imprisoned not more than one year or both. ${ }^{23}$

"Take" is defined as including to pursue, shoot, shoot at, poison, wound, kill, capture, trap, collect, molest or disturb. ${ }^{24}$ A second or further transgression of these provisions may attract a fine of not more than $\$ 10000$ or imprisonment for not more than two years, or both. ${ }^{25}$ Under the Criminal Fines Improvement Act of 1987, the maximum fine for a first transgression has been changed to $\$ 100000 .^{26}$ Each taking of an eagle, or other act prohibited by these provisions, constitutes a separate transgression. ${ }^{27}$ Provision is also made for a reward to be paid to a person or persons giving information which leads to a conviction. ${ }^{28}$ In addition to these criminal penalties, ${ }^{29}$ provision is also made for civil penalties ${ }^{30}$ up to a maximum of $\$ 5000$, and for the cancellation of grazing agreements which a transgressor may have had in respect of federal lands. ${ }^{31}$ The Act makes provision that the Secretary of the Interior may issue permits for the taking and using of the eagles for certain scientific, exhibition, and religious purposes. ${ }^{32}$

A second sharp decline in Bald Eagle numbers followed after the Second World War. Research showed that the widespread use of so-called organochlorine compounds as insecticides, of which Dichlor-diphenyl-trichlorethane (DDT) was the most wellknown and subsequently the most notorious, was impacting negatively upon the Bald Eagle, other bird of prey species and indeed many other life-forms. ${ }^{33}$ The Fish and Wildlife Service ${ }^{34}$ listed the Bald Eagle as Endangered under the Endangered

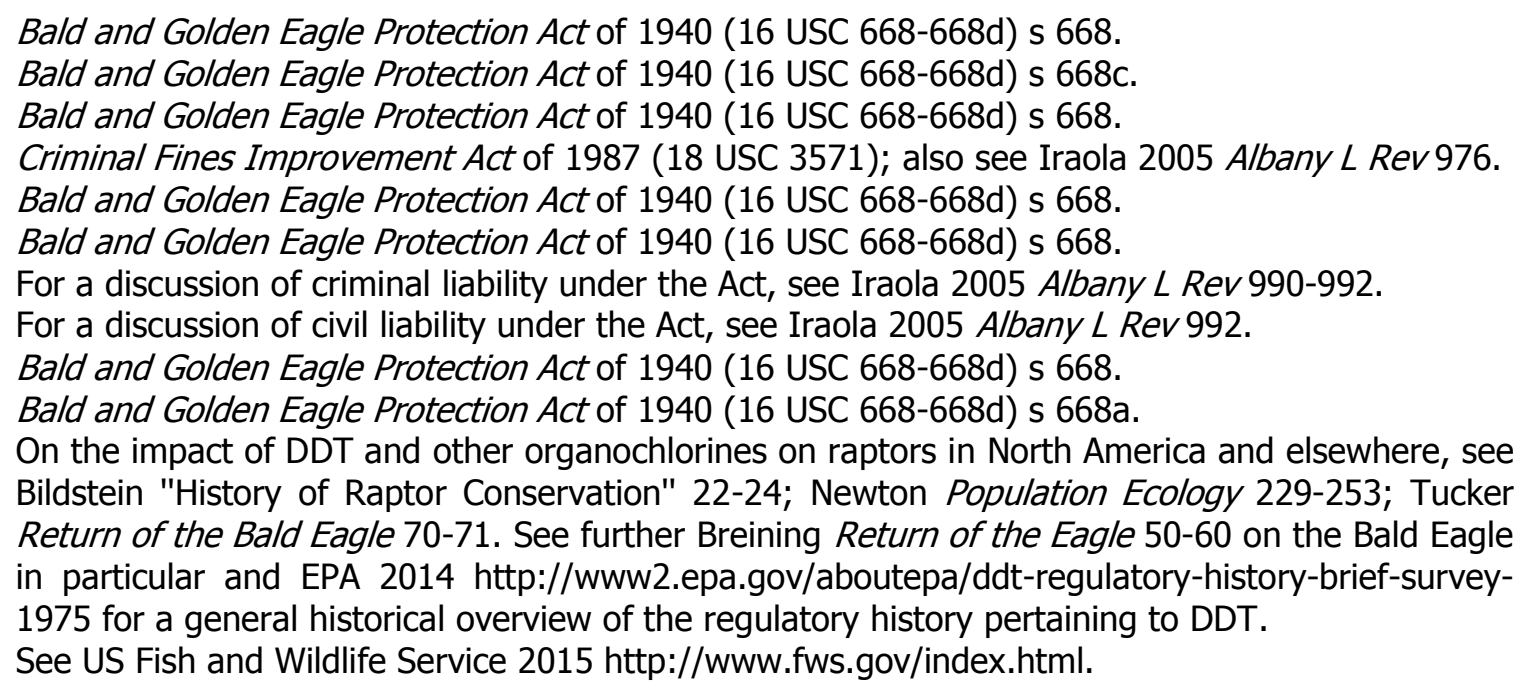
Return of the Bald Eagle 70-71. See further Breining Return of the Eagle 50-60 on the Bald Eagle

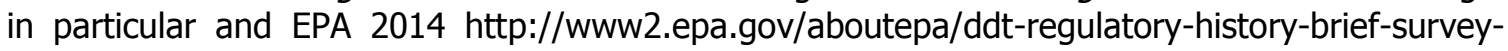
1975 for a general historical overview of the regulatory history pertaining to DDT. 
Species Preservation Act ${ }^{35}$ from 1967. ${ }^{36}$ The Environmental Protection Agency ${ }^{37}$ banned the use of DDT in 1973. ${ }^{38}$ When the Endangered Species Act ${ }^{39}$ superseded the Endangered Species Preservation Act in 1973, the Bald Eagle retained its status as an Endangered species. ${ }^{40}$

The above-mentioned legislative interventions, as well as the Migratory Bird Treaty $A c t_{1}^{41}$ laid the legal foundation for the conservation of the Bald Eagle. The conservation initiatives on behalf of the species proved to be highly successful. Bald Eagle numbers in the lower forty-eight states grew from 417 nesting pairs in 1963 to an estimated 9789 nesting pairs in 2007.42 In 1995, the Fish and Wildlife Society "downlisted" the Bald Eagle from Endangered to Threatened in the lower forty-eight states $^{43}$ and in 2007 the Bald Eagle was delisted under the Endangered Species Act. ${ }^{44}$ The legal protection bestowed upon the Bald Eagle by the other Acts ${ }^{45}$ remained in force. ${ }^{46}$

35 Endangered Species Preservation Act of 1966 (Pub law 89-699). On the history of the Act and its successors, see Scott, Goble and Davis "Introduction" 6-7.

$3632 F R 4001$. This listing applied to Bald Eagle populations south of the $40^{\text {th }}$ parallel. See Noecker "Revision" 143.

37 See EPA 2015 http://www2.epa.gov/aboutepa.

$38 \quad 37$ FR 13369; see further EPA 2014 http://www2.epa.gov/aboutepa/ddt-ban-takes-effect.

39 Endangered Species Act of 1973 (16 USC 1531-1544). See US Fish and Wildlife Service 2011 http://www.fws.gov/endangered/esa-library/pdf/history_ESA.pdf; US Fish and Wildlife Service 2013 http://www.fws.gov/endangered/laws-policies/timeline.html.

40 In 1978 the Fish and Wildlife Service listed all remaining populations in the lower 48 states as Endangered, except for populations in Michigan, Minnesota, Wisconsin, Oregon and Washington, where the Bald Eagle was listed as Threatened (43 FR 6233). See Noecker "Revision" 143.

41 Migratory Bird Treaty Act of 1994 (16 USC 703-712). Eagles were not originally protected under this Act, but in 1972 a treaty with Mexico, which was incorporated into the Act, was amended to extend protection to eagles; see Convention for the Protection of Migratory Birds and Game Mammals (1936). See in general Bean and Rowland Evolution of National Wildlife Law 63-93, 97; Doub Endangered Species Act 91-94.

42 US Fish and Wildlife Service 2013 http://www.fws.gov/midwest/eagle/recovery/qandas.html.

4360 FR 3600136010.

4472 FR 37346.

45 The Bald and Golden Eagle Protection Act of 1940 (16 USC 668-668d) and the Migratory Bird Treaty Act of 1994 (16 USC 703-712).

46 US Fish and Wildlife Service 2013 http://www.fws.gov/midwest/eagle/recovery/qandas.html. 


\subsection{The Golden Eagle and the risk of misidentification}

The Golden Eagle ${ }^{47}$ is another big raptor species, similar in size to the Bald Eagle, and it also occurs widely in North America. While the Bald Eagle preys mainly on fish and water birds and is therefore usually associated with aquatic habitats, the Golden Eagle hunts terrestrial prey and often occurs far from water. Whereas the Bald Eagle usually sites its nest in trees close to water, the Golden Eagle usually breeds on cliffs or trees in mountainous or hilly terrain. Nevertheless, in many parts of North America, Bald and Golden Eagles may be encountered side-by-side. An adult Bald Eagle has a very distinctive appearance and is unlikely to be confused with any other bird of prey species in North America. ${ }^{48}$ However, Bald Eagles attain their distinctive adult plumage only in their fifth or sixth year, and the juvenile (first) plumage and subsequent immature plumages are less distinctive. ${ }^{49}$ Before attaining its distinctive adult plumage, a Bald Eagle may be misidentified as a Golden Eagle. ${ }^{50}$

In the USA, the Golden Eagle has been subjected to intense human persecution. Stock farmers blamed the eagles for lamb losses and this served as an incentive to kill eagles. In Texas and other western states the persecution was taken to an extreme. Expert marksmen took to the air to kill Golden Eagles. They used small aircraft to locate flying eagles, and shot down thousands of them. ${ }^{51}$

47 Aquila chrysaetos. For details on the biology and conservation status of the Golden Eagle, see BirdLife International $2015 \mathrm{http} / / /$ www.birdlife.org/datazone/speciesfactsheet.php?id=3537; Del Hoyo, Elliot and Sargatal Handbook of the Birds of the World 197-198; Ferguson-Lees and Christie Raptors of the World (2001) 742-746; Global Raptor Information Network 2015 http://www.globalraptors.org/grin/SpeciesResults.asp?specID=8162; $\quad$ IUCN 2014 http://www.iucnredlist.org/details/full/22696060/0; Johnsgard Hawks, Eagles and Falcons of North America 260-268; Watson Golden Eagle.

48 Ferguson-Lees and Christie Raptors of the World (2001) 401; but see Dunne, Sibley and Sutton Hawks in Flight 151.

49 Ferguson-Lees and Christie Raptors of the World (2001) 401.

50 Ferguson-Lees and Christie Raptors of the World (2001) 401; Dunne, Sibley and Sutton Hawks in Flight 145; Wheeler Raptors of Eastern North America 134-135.

51 Watson Golden Eagle 314-315 refers to an estimate of 20000 eagles killed in the southwestern USA in a 20-year period; see further Bodio An Eternity of Eagles 160-163; Gordon Golden Eagle 133-138; Laycock Autumn of the Eagle 178-191; Palmer "Golden Eagle" 218-220. 


\subsection{Legal protection for the Golden Eagle}

Even though many Golden Eagles were killed and Golden Eagle populations suffered declines in some parts of the USA, the species was never classified as Endangered nationwide. ${ }^{52}$ The Golden Eagle has therefore never been quite as high a conservation priority as the Bald Eagle in the USA. ${ }^{53}$

Nevertheless, in 1962, the Bald Eagle Protection Act was amended to bestow comprehensive protection onto the Golden Eagle as well, and the Act was henceforth to be known as the Bald and Golden Eagle Protection Act. The Enacting Clause of the amendment worded the rationale behind this amendment as follows:

Whereas the population of the golden eagle has declined to such an alarming rate that it is now threatened with extinction; and

Whereas the golden eagle should be preserved because of its value to agriculture in the control of rodents; and

Whereas protection of the golden eagle will afford greater protection for the bald eagle, the national symbol of the United States of America, because the bald eagle is often killed by persons mistaking it for the golden eagle:

Now, therefore, be it

Resolved by the Senate and the House of Representatives of the United States of America in Congress assembled, That the first two sections of the Act of June 8, 1940 ... are hereby amended to read as follows: "Whoever, within the United States or any place subject to the jurisdiction thereof, without being permitted to do so as hereinafter provided, shall take, possess, sell, purchase, barter, offer to sell, purchase or barter, transport, export or import at any time or any manner, any bald eagle commonly known as the American eagle, or any golden eagle, alive or dead, or any part, nest, or egg thereof of the foregoing eagles, shall be fined ... or imprisoned ..., or both ... ${ }^{4}$

Notably, three reasons were stated why the Golden Eagle was brought into the protective sphere of the Act. It was accepted that giving legal protection to the Golden Eagle was in itself a worthy goal, first, because of a decline in Golden Eagle

52 In some states it has been listed as Endangered. See Global Raptor Information Network 2012 http://globalraptors.org/grin/SpeciesExtended.asp?specID=8162\&catID=2007\&childID=149\&sSp eciesName=Aquila chrysaetos.

53 See US Fish and Wildlife Service 2011 http://www.fws.gov/migratorybirds/ NewReportsPublications/FactSheets/Golden_Eagle_Status_Fact_Sheet[1].pdf.

54 Joint Resolution: To Provide Protection for the Golden Eagle (Pub L 87-884, Oct 24 1962, 76 Stat 12466) (emphasis added and some italic print in original text changed to roman print). 
populations; and second, because the Golden Eagle was valuable to agricultural interests by controlling rodent numbers. The third reason is very interesting and highly relevant to the topic of this contribution: because Bald Eagles had been killed under the mistaken impression that they were Golden Eagles, bestowing protection on the Golden Eagle would also strengthen the legal protection of the Bald Eagle. After this amendment of the Act, the killing of any wild eagle in the USA would in principle be unlawful. The possibility that misidentification of eagle species would enable a person to kill an immature Bald Eagle and yet escape the penalty of the law by saying that he or she mistook it for a Golden Eagle was thus eliminated.

The last-mentioned reason for the extension of legal protection to the Golden Eagle has been cited in ornithological ${ }^{55}$ and legal texts. ${ }^{56}$ It has also received explicit recognition by the courts. ${ }^{57}$ In McAllen Grace Brethren Church v Salazar, the Court of Appeals for the Fifth Circuit stated:

\begin{abstract}
We agree with the Tenth and Ninth Circuits that protecting bald eagles qualifies as a compelling interest because of its status as our national symbol, regardless of whether the eagle still qualifies as an endangered species ... In passing the Eagle Protection Act, Congress specifically stated that the purpose was to preserve the bald eagle because of its special status as our national symbol ..., and in amending the Act, Congress stated that protecting the golden eagle would further this purpose because the bald eagle is often killed by persons mistaking it for the golden eagle... ${ }^{58}$
\end{abstract}

New conservation threats to the Golden Eagle have emerged, and have in a sense vindicated the first reason for the extension of legal protection to the Golden Eagle under the Bald and Golden Eagle Protection Act. In a most ironic development, the deployment of wind energy turbines has emerged as a potentially important threat to Golden Eagles, with a wind-farm in the Altamont Pass in California having earned

$55 \quad$ Bildstein "History of Raptor Conservation" 12; Bodio An Eternity of Eagles 162.

56 Bean and Rowland Evolution of National Wildlife Law 94; De Meo 1995 Hastings Const LQ 780781; Kovacs 2013 Loy LA L Rev 63; Perkins 2000 Envtl L 705; Wisch 2014 https://www.animallaw.info/article/detailed-discussion-bald-and-golden-eagle-protection-act; Worthen 2005 U Colo L Rev $991 \mathrm{n} 7$.

57 McAllen Grace Brethren Church $v$ Salazar (5th Cir 2014) Unreported Case No 13-40326 of 20 August 2014; United States v Wilgus 638 F 3d 1274 (10th Cir 2011) 1278; United States v Friday 525 F 3d 938 (10th Cir 2008) 944; United States v Hardman 297 F 3d 1116 (10th Cir 2002) 1122; United States v Fryberg 622 F 2d 1010 (9th Cir 1980) 1016.

58 McAllen Grace Brethren Church v Salazar (5th Cir 2014) Unreported Case No 13-40326 of 20 August 2014 10, emphasis added. 
itself particular notoriety in this regard. ${ }^{59}$ Electrocution and collision with conventional power structures also cause many eagle deaths. ${ }^{60}$ Ingestion of lead, usually in the form of shot used by hunters on game mammals or birds, is a further threat to all scavenging raptors, including the Golden Eagle, which is known to take carrion. ${ }^{61}$ Other forms of poisoning are also sources of mortality. ${ }^{62}$

Another threat to the Golden Eagle is the need of Native Americans to get access to eagle parts and eagle feathers for religious use. This interest of the Native Americans is given recognition in the Bald and Golden Eagle Protection Act of 1940 and certain exceptions to the prohibition on possession of eagle parts are allowed specifically for this purpose. ${ }^{63} \mathrm{~A}$ central eagle depository situated in Denver, Colorado receives eagle feathers and carcasses for distribution among Native Americans. ${ }^{64}$ Members of Native American tribes that are recognised by the federal government ${ }^{65}$ may apply to the depository to be given eagle feathers and carcasses, and when their applications are granted they may lawfully possess such feathers or carcasses. Thus the Bald and Golden Eagle Protection Act specifically makes provision for a balance to be struck between the protection of the eagles and potentially conflicting human interests, such as the interests of the Native Americans. The resolution of such conflicts under the Act may not necessarily always be to the satisfaction of those who are concerned about the conservation of eagles, or those who are concerned about the religious freedom of the Native Americans, or those who are concerned about finding a satisfactory balance between the two conflicting interests. ${ }^{66}$ Nevertheless, the position under the Act is clearly better than a scenario where the eagles would have no or limited legal protection and would be subject to unfettered human exploitation

\footnotetext{
59 See eg Thelander and Smallwood "Altamont Pass" 25-46; Watson Golden Eagle 328-329.

60 See Watson Golden Eagle 325-328.

61 See Watson Golden Eagle 303. In respect of lead poisoning in vultures, see Behmke et a/ 2015 Environment International 51-55.

62 See Watson Golden Eagle 302.

63 Bald and Golden Eagle Protection Act of 1940 (16 USC 668-668d) s 668a. For discussions of case law dealing with this issue, see Iraola 2005 Albany L Rev 980-984; Kovacs 2013 Loy LA L Rev6871 83-85; Worthen 2005 U Colo L Rev 994-1002.

64 US Fish and Wildlife Service 2015 http://www.fws.gov/eaglerepository/.

6564 FR 50467 50473; see further Iraola 2005 Albany L Rev 979; Kovacs 2013 Loy LA L Rev 64.

66 See eg Bodio An Eternity of Eagles 168-171; De Meo 1995 Hastings Const LQ 780-781; Kovacs 2013 Loy LA L Rev 56 et seq.
} 
and persecution without any legal checks to ensure that those practices were sustainable. ${ }^{67}$

\section{Discussion}

\subsection{Thoughts on the suitability of the American solution for use in other jurisdictions}

As seen, the possibility that the two American eagle species could be confused with each other was cited as a reason for bestowing protection on both of them. This solution of the problem of misidentification of a protected species worked in favour of both the American eagle species. The question arises whether this strategy is a suitable one for adoption in other jurisdictions where members of protected species may be misidentified and mistakenly be thought to be members of commoner species. More pertinently, for the purpose of this contribution, the question is whether the American solution is suitable for application in South African environmental law to enhance the legal protection of South African birds of prey.

A number of considerations may be relevant in this regard. First, it is probably good for conservation that as many species as possible are legally protected. Second, in the interest of not unduly burdening the citizens and state officials in a given jurisdiction, it is probably good that the smallest possible number of species is legally protected. A balance must be found somewhere between these two positions. A key part of this balance could very well be the adoption of a principle that factually endangered species should in principle receive a higher level of legal protection than commoner species. In view of these considerations, could it be regarded as desirable, on grounds of legal policy, to endow not only a factually endangered species, but also a commoner species with which the endangered species may be confused, with a high level of legal protection? It is submitted that a positive answer may be the correct one.

67 The demand for eagles for human use exceeds the bounds of sustainability; see Kovacs 2013 2013 Loy LA L Rev 71-79. 
It should be borne in mind that other considerations made the case in favour of the enhanced legal protection of the Golden Eagle even more compelling. Although the Golden Eagle was not formally classified as Endangered nationwide in the USA, and even though it occurred and still occurs in substantial numbers in large parts of the USA, it was not simply just another common species. As a large raptor species, the Golden Eagle was subject to certain factors that could easily have contributed to making its factual conservation status much less secure. In fact, as has been noted above, the Congress of the USA expressed a perception that the Golden Eagle had been threatened with extinction. ${ }^{68}$ Large birds of prey seldom occur in high densities and have a slow reproductive rate. For this reason, increased mortality due to human-induced causes can render such species vulnerable far more easily than species that occur in high densities and have a fast rate of reproduction. ${ }^{69} \mathrm{In}$ fact, this is precisely what happened to the Bald Eagle in the lower states of the USA, where its factual conservation status deteriorated from common and widespread to Endangered over a relatively short period of time. The Golden Eagle could conceivably have suffered a similar fate if such factors as persecution, poisoning, mortality induced by human-made structures such as wind turbines, and exploitation for religious purposes by Native Americans, were allowed to take their course unchecked and unabated. These factors strengthen the case in favour of the heightened legal protection of the Golden Eagle, in addition to the above-mentioned consideration that such protection of the Golden Eagle would also strengthen the legal protection of the Bald Eagle.

\subsection{Suitability of application in South African law}

If this line of reasoning is applied in respect of South African birds of prey, it is submitted that a strong case can be made in favour of extending protection under the national biodiversity legislation to more species than the small number of species currently enjoying such protection. This is particularly relevant in the case of the larger species such as vultures and eagles, which typically occur in comparatively low

68 Joint Resolution: To Provide Protection for the Golden Eagle (Pub L 87-884, Oct 24 1962, 76 Stat 12466); see the quotation in para 2.3 above.

69 Katzner and Tingay "Eagle Diversity, Ecology and Conservation" 19. 
densities and have a slow reproductive rate. If, for the purpose of illustration, the South African eagle species are considered as a group of species representative of the South African raptors, it should be noted that only four species are currently protected under the national biodiversity legislation: ${ }^{70}$ the Bateleur, ${ }^{71}$ the Tawny Eagle ${ }^{72}$ the Martial Eagle ${ }^{73}$ and the Southern Banded Snake Eagle. ${ }^{74}$ These species are listed as Vulnerable, that is, they are judged to face an extremely high risk of extinction in the wild in the medium term, although they are not Critically Endangered or Endangered Species. ${ }^{75}$

This means that twelve South African eagle species are not protected by the national biodiversity legislation. ${ }^{76}$ Those twelve species do enjoy protection under provincial

70 Section 56 of NEMBA, read with the TOPS Regulations (GN R152 in GG 29657 of 23 February 2007) and the Lists of Critically Endangered, Endangered, Vulnerable and Protected Species (GN R151 in GG 29657 of 23 February 2007). A new Threatened or Protected Species list was published for comment in April 2013: Publication of Lists of Species that are Threatened or Protected, Activities that are Prohibited and Exemption from Restriction (Gen N 389 in GG 36375 of 16 April 2013). According to the proposed new list, the following eagle species are classified as Vulnerable: Bateleur Terathopius ecaudatus, Martial Eagle Polemaetus bellicosus, and Tawny Eagle Aquila rapax. The Southern Banded Snake Eagle Circaetus fasciolatus is no longer listed, and no other eagle species have been added. Subsequently, a revised new Threatened or Protected Species list was published for comment in March 2015: Publication of Lists of Species that are Threatened or Protected, Activities that are Prohibited and Exemption from Restriction (Gen N 256 in GG 38600 of 31 March 2015). The same eagle species are listed as in the original new list, but their status has been changed to Endangered.

Terathopius ecaudatus.

Aquila rapax.

Polemaetus bellicosus.

Circaetus fasciolatus.

Section 56(1)(c) of NEMBA. A Critically Endangered Species is any indigenous species facing an extremely high risk of extinction in the wild in the immediate future; s 56(1)(a). An Endangered Species is any indigenous species facing a high risk of extinction in the wild in the near future, although it is not a Critically Endangered Species; s 56(1)(b).

76 In total, sixteen raptor species known as eagles occur in South Africa. They are the African Fish Eagle Haliaeetus vocifer, Bateleur Terathopius ecaudatus, Brown Snake Eagle Circaetus cinereus, Black-chested Snake Eagle Circaetus pectoralis, Southern Banded Snake Eagle Circaetus fasciolatus, Verreaux's Eagle (also known as the Black Eagle in Southern Africa) Aquila verreauxii, Tawny Eagle Aquila rapax, Steppe Eagle Aquila nipalensis, Lesser Spotted Eagle Clanga pomarina, African Hawk-Eagle Aquila spilogaster, Wahlberg's Eagle Hieraaetus wahlbergi, Booted Eagle Hieraaetus pennatus, Ayres's Eagle Hieraaetus ayresii, Long-crested Eagle Lophaetus occipitalis, Martial Eagle Polemaetus bellicosus, and Crowned Eagle Stephanoaetus coronatus. For information on these species and their occurrence in South Africa, see Hockey, Dean and Ryan Roberts Birds of Southern Africa 481-483, 493-500, 528-542; Steyn Birds of Prey of Southern Africa 59-126, 129-144. For information on these species in a global context, see Ferguson-Lees and Christie Raptors of the World (2001) 394-396, 450-457, 724-727, 730-736, 748-750, 753-761, 763-765, 769-770, 788-790, 792-794. 
legislation, but this protection is not satisfactory in all respects. ${ }^{77}$ Penalties provided for in provincial legislation are typically lower than those provided for in national legislation, and hence the provincial sanctions have a lesser deterrent value. Provincial nature conservation offices also typically face severe capacity challenges and hence enforcement suffers. In some provinces, the provincial legislation bestows immunity on landowners and persons authorised by the landowners for killing raptors on their land. ${ }^{78}$ Thus the legal protection afforded to the eagles cannot be enforced against those persons who may perceive themselves to have the most justifiable interest in killing eagles.

To return to the central topic of this contribution, and staying with South African eagles as representative of South African raptors, the potential for the misidentification of the four eagle species protected under national legislation in South Africa clearly exists. Immature Bateleurs can be confused with Brown Snake Eagles, ${ }^{79}$ Tawny Eagles can be confused with a number of eagle species with brown feathering such as the Wahlberg's Eagle, the Steppe Eagle and the Lesser Spotted Eagle, $^{80}$ the adult Martial Eagle can be confused with the adult Black-chested Snake Eagle, ${ }^{81}$ and the Southern Banded Snake Eagle may conceivably be confused with a number of goshawks and the African Cuckoo Hawk. ${ }^{82}$ Applying the line of reasoning established above, a case can be made for the extension of legal protection under the national biodiversity legislation to most or all of these misidentification-prone species.

In fact, this argument could be taken further. If, by way of example, only the larger South African raptor species are considered, ${ }^{83}$ a case can be made that all vulture and eagle species should be protected under the National Environmental

See Knobel 2013 PER/PELJ paras 3.4, 5.2.1; Knobel 2015 De Jure para 3.

78 Eg Nature and Environmental Conservation Ordinance 19 of 1974 s 27; see Knobel 2013 PER/PEL para 3.4. The Ordinance is in force in the Western Cape and Eastern Cape provinces.

79 Ferguson-Lees and Christie Raptors of the World (2001) 456; Kemp and Kemp Birds of Prey 55.

80 Ferguson-Lees and Christie Raptors of the World (2001) 732; Kemp and Kemp Birds of Prey.

81 Ferguson-Lees and Christie Raptors of the World (2001) 793; Kemp and Kemp Birds of Prey 75.

82 Ferguson-Lees and Christie Raptors of the World (2001) 453.

83 Not implying in any way that other raptor species are less deserving of high-level legal protection. 
Management: Biodiversity Act 10 of 2004 (NEMBA). The Act makes provision for a special category of species that are not Critically Endangered, Endangered or Vulnerable, but are nevertheless Protected because they have such a high conservation value or national importance that they require national protection. ${ }^{84}$ It is submitted that this is the appropriate legal status for all the South African vulture and eagle species that do not merit inclusion in the Critically Endangered, Endangered or Vulnerable categories.

The additional considerations that strengthened the case in favour of heightened legal protection of the Golden Eagle in America are arguably also applicable to all of these species in South Africa. All of these large South African raptor species are lowdensity species with slow reproductive rates. Many of these species will soon be "uplisted" to a less favourable factual conservation status in a revised Red List of the Birds of South Africa, Lesotho and Swaziland. The list is currently in preparation under the auspices of the foremost South African non-governmental organization involved in bird conservation, BirdLife South Africa, in cooperation with the Percy Fitzpatrick Institute of African Ornithology, based at the University of Cape Town. In the new Red List, no fewer than twelve South African raptor species are likely to be listed as Endangered ${ }^{85}$ and two as Critically Endangered. ${ }^{86}$ Five raptor species are likely to be listed as Vulnerable ${ }^{87}$ and three raptor species as Near-threatened. ${ }^{88}$ If these results are compared with the listings in the previous and now outdated Red List, an alarming downward population trend for raptors as a group is clearly revealed: twenty raptor species will be "uplisted" to a less favourable factual conservation status; while only four are "downlisted" to a more favourable

84 Section 56(1)(d) of NEMBA.

85 They are the Hooded Vulture Necrosyrtes monachus; Cape Vulture Gyps coprotheres, Whitebacked Vulture Gyps africanus, Lappet-faced Vulture Torgos tracheliotos, White-headed Vulture Trigonoceps occipitalis, Black Harrier Circus maurus, African Marsh Harrier Circus ranivorus, Bateleur Terathopius ecaudatus, Southern Banded Snake Eagle Circaetus fasciolatus; Martial Eagle Polemaetus bellicosus, Tawny Eagle Aquila rapax and Pel's Fishing Owl Scotopelia peli.

86 Bearded Vulture Gypaetus barbatus and Taita Falcon Falco fasciinucha.

87 Verreaux's Eagle Aquila verreauxii; Crowned Eagle Stephanoaetus coronatus, Lanner Falcon Falco biarmicus, Secretary-bird Sagittarius serpentarius and African Grass Owl Tyto capensis.

88 Pallid Harrier Circus macrourus, Sooty Falcon Falco concolor and Red-footed Falcon Falco vespertinus. 
status. ${ }^{89}$ Fifty-five species will not change in status in the new list, but these species include one Vulnerable and one Near-threatened species in their ranks. The Red List does not have legal force, but because it represents the best scientific assessment of the factual conservation status of South African bird species, it should influence which species are listed under the legislation dealing with the conservation of biodiversity. In respect of raptors, NEMBA is now arguably out of step with reality. ${ }^{90}$

Furthermore it is noteworthy that, in the ranks of larger raptor species, even comparatively common species already show declining population trends in some regions even though the species may not yet be judged to be in trouble nationwide. The Wahlberg's Eagle is a good example. It is a breeding summer migrant to Southern Africa, and in the summer months is probably the commonest eagle species in South Africa's Kruger National Park, which is known for its rich raptor populations. ${ }^{91}$ Globally it is judged as Least Concern by the International Union for the Conservation of Nature ${ }^{92}$ and BirdLife International. ${ }^{93}$ Nevertheless, in some parts of South Africa ornithologists have noted sharp population declines, ${ }^{94}$ and while the causative factors may still be a matter for speculation, these trends, and the potential vulnerability of even a comparatively common raptor species highlighted by these trends, should not be ignored.

Most of these large raptor species are beneficial to farming interests. Vultures perform a valuable role in disposing of large mammal carcasses in remoter areas

89 M Taylor of BirdLife South Africa supplied the information about the new Red List and this is acknowledged with gratitude.

90 A revised new Threatened or Protected Species list that has been published for comment in March 2015 (Publication of Lists of Species that are Threatened or Protected, Activities that are Prohibited and Exemption from Restriction (Gen N 256 in GG 38600 of 31 March 2015)) is more up to date in so far as it lists three raptor species as Critically Endangered (Bearded Vulture Gypaetus barbatus, Taita Falcon Falco fasciinucha and the locally practically extinct Egyptian Vulture Neophron percnopterus) and eight raptor species as Endangered (Hooded Vulture Necrosyrtes monachus, Cape Vulture Gyps coprotheres, White- backed Vulture Gyps africanus, Lappet-faced Vulture Torgos tracheliotos, White-headed Vulture Trigonoceps occipitalis, Bateleur Terathopius ecaudatus, Martial Eagle Polemaetus bellicosus, and Tawny Eagle Aquila rapax. However, no raptor species are listed in the Vulnerable and Protected categories.

91 Newman Kruger National Park 68.

92 IUCN 2015 http://www.iucnredlist.org/details/full/22696072/0.

93 BirdLife International 2015 http://www.birdlife.org/datazone/speciesfactsheet.php?id=3540.

94 Eg Tarboton "Foreword" iv. 
where they are unlikely to get prompt attention from people. This is a potentially highly important function in the prevention of the spread of disease. Scientific investigation has recently revealed that the vultures of the Americas are able to ingest bacteria, which abound on decaying carcasses and are highly dangerous to other organisms, with no ill effects to the vultures. ${ }^{95}$ The vultures of Africa and Eurasia are likely to have a similar ability; otherwise they would probably not have been able to exploit carrion as a source of food. ${ }^{96}$ Most South African eagles benefit farming interests by controlling potential problem species for agriculture. Such species include rodents, seed-eating birds, larger mammals like monkeys and dassies that can cause damage to crops or grazing, and even small carnivorous mammals, such as jackals and caracals, which may kill small livestock. ${ }^{97}$ In the case of the Verreaux's Eagle, which normally preys on hyrax, but may kill lambs and goat kids, a carefully substantiated study showed that the presence of a resident pair of these eagles on a Karoo sheep farm could still benefit the farmer financially. The study showed that the presence of the eagles would prevent hyrax from venturing far from protective hills and rocky outcrops. This would minimise competition between the hyrax and sheep for grazing, and the financial saving annually gained in this way would typically exceed the cost of the number of lambs likely to be taken by the eagle pair in the course of a year. ${ }^{98}$

Unfortunately some members of farming communities continue to harbour old prejudices in terms of which all birds of prey are regarded as inimical to farming interests. Such prejudices are seldom based on carefully verified facts, and may be based on erroneous conclusions made from incomplete observations. To cite one example, it is well-known in ornithological circles that most eagle species will at times eat carrion. Therefore an observation of an eagle feeding on a lamb does not necessarily justify a conclusion that the eagle has actually killed the lamb. ${ }^{99}$ Sadly,

\footnotetext{
95 Roggenbuck et al 2014 http://www.nature.com/ncomms/2014/141125/ncomms6498/ full/ncomms6498.html.

96 McKechnie 2015 African Birdlife 13.

97 See eg Ferguson-Lees and Christie Raptors of the World 749-750, 789, 793; Hockey, Dean and Ryan Roberts Birds of Southern Africa 532, 538, 541.

98 Davies 1999 Journal of Raptor Research 67-72.

99 See Bekker et al Innocent until Proven Guilty 1-4.
} 
the persecution of birds of prey is still a reality in South Africa. ${ }^{100}$ Such persecution is often illegal under provincial legislation but, as noted above, there are problems with enforcement and in some provinces the landowners and persons acting with their authority do not commit an offence if they kill or trap the species protected under provincial legislation. A farmer may know that killing a Martial Eagle, Tawny Eagle, Bateleur or Southern Banded Snake Eagle may lead to prosecution under national legislation, but in such instances may well plead misidentification and go scot-free because intention cannot be proved. ${ }^{101}$ For this reason, and all the other reasons that point towards the heightened vulnerability of these species, it is submitted that the American solution in respect of the Bald Eagle and Golden Eagle is eminently suitable to be applied to the protection of South African vulture and eagle species under South African national law.

These eagles and vultures, as larger raptor species, have been selected for illustrative purposes in this contribution, but similar arguments also apply to most of the smaller raptor species occurring in South Africa. Some of them may not occur in such low densities as the larger raptor species, and their reproductive rates may be faster than those of the larger species, but compared to most other birds of similar sizes these smaller raptors may still be more vulnerable to factors inducing negative population trends. ${ }^{102}$ Because they may be involved or may be perceived to be involved in the killing of domestic fowl or racing pigeons or ornamental pigeons, such smaller birds of prey may also be the targets of human persecution. Some species are sought after for falconry, and falconers who do not abide by the rules of falconry associations may take birds from the wild for their own use or for illegal trade. ${ }^{103}$ In

100 African raptors $2011 \mathrm{http}: / /$ www.africanraptors.org/an-interview-with-andre-botha-about-raptorconservation-in-south-africa/; EWT 2014 https://www.ewt.org.za/BOP/platberg.html; EWT 2012 https://www.ewt.org.za/eBooks/booklets/Eagles\%20and\%20Farmers\%20booklet.pdf; Barnes Important Bird Areas 35. Raptor poisoning incidents, in particular, appear to be escalating; see EWT 2014 https://www.ewt.org.za/conreports/2014/book.swf.

101 See para 1 above.

102 Note eg that one falcon species will henceforth be listed as Critically Endangered (Taita Falcon Falco fasciinucha); one as Vulnerable (Lanner Falcon Falco biarmicus) and one as Nearthreatened (Red-footed Falcon Falco vespertinus) in the new Red List for South Africa, Lesotho and Swaziland.

103 See eg International Association for Falconry and Conservation of Birds of Prey 2013 http://www.iaf.org/Legislation.php; Lombard Date Unknown http://www.anderson africa.co.za/pamphlets/Falconry.pdf. 
addition, the rarer species, which are currently protected under national legislation, may also be confused with commoner species and consequently misidentified. A small minority of raptor species may not give conservationists any cause for concern at present, with the almost ubiquitous Black-shouldered Kite ${ }^{104}$ perhaps constituting the most notable example. However, the Black-shouldered Kite is such a prolific hunter of rodents, and is accordingly such a beneficial species to farming interests, that it is arguably worthy of a high level of legal protection anyway. Similar arguments are also applicable to the nocturnal birds of prey, the owls.

\section{Conclusion}

It is submitted that the time has come to treat the rich but potentially fragile raptor heritage of South Africa with the respect and care that it deserves, by proclaiming all South African bird of prey species to be fully protected under national legislation. If such species do not qualify for inclusion in the graver categories of Critically Endangered, Endangered or Vulnerable, they should at least be classified in the category of Protected, for which NEMBA already makes provision. As noted, the criterion for listing as Protected is that the species has such a high conservation value or national importance that it requires national protection, although it is not Critically Endangered, Endangered or Vulnerable. ${ }^{105}$ It is submitted that this criterion could hardly be more neatly tailored to the needs of the South African bird of prey species that are not already listed in terms of NEMBA.

In addition, by bestowing full legal protection on all its bird of prey species, South Africa will be more in step with other trend-setting jurisdictions on the globe, ${ }^{106}$ and

104 Elanus caeruleus. Dickinson and Remsen Checklist 234 use the name Black-winged Kite for this species, and the name Black-shouldered Kite for a related Australian species, Elanus axillaris. In Southern Africa Elanus caeruleus is widely known as the Black-shouldered Kite, see Hockey, Dean and Ryan Roberts Birds of Southern Africa 478; Steyn Birds of Prey of Southern Africa 46.

105 Para 3.2 above.

106 Eg the Convention on the Conservation of Migratory Species of Wild Animals (1979) (Bonn Convention) includes all migratory raptor species as species which have an unfavourable conservation status and which require international agreements for their conservation and management, as well as those which have a conservation status which would significantly benefit from the international co-operation that could be achieved by an international agreement (Appendix II); the Convention on the Conservation of European Wildlife and Natural Habitats 
South Africa will also have proved itself willing to give greater effect to its undertakings to give legal protection to migratory raptors in the Memorandum of Understanding on the Conservation of Migratory Birds of Prey in Africa and Eurasia (the Raptors Mol), ${ }^{107}$ which was entered into under the Convention on the Conservation of Migratory Species of Wild Animals. ${ }^{108}$

Last, but not least, following this course will also ensure that the danger of misidentification will not serve as a ground for a defence that allows a person to kill a protected raptor with impunity.

(1979) (Bern Convention) includes all raptor species as "strictly protected species" (Appendix II); and the Convention on International Trade in Endangered Species of Wild Fauna and Flora (1973) (CITES) includes almost all raptor species as species either threatened with extinction or that may become threatened in future unless international trade is strictly regulated (Appendices I and II).

107 UNEP/CMS Secretariat 2014 http://www.cms.int/raptors/en/legalinstrument/birds-prey-raptors; Knobel 2013 PER/PELJ para 3.1.4.

108 Convention on the Conservation of Migratory Species of Wild Animals (1979) (Bonn Convention). See CMS 2014 www.cms.int; Knobel 2013 PER/PELJ para 3.1.4. 


\section{BIBLIOGRAPHY}

\section{Literature}

Barnes Important Bird Areas

Barnes KN (ed) The Important Bird Areas of Southern Africa (BirdLife South Africa Randburg 1998)

Bates Environmental Law in Australia

Bates G Environmental Law in Australia $8^{\text {th }}$ ed (LexisNexis Butterworths Chatswood 2013)

Bean and Rowland Evolution of National Wildlife Law

Bean MJ and Rowland MJ The Evolution of National Wildlife Law $3^{\text {rd }}$ ed (Praeger Westport 1997)

Behmke et a/2015 Environment International

Behmke S et al "Chronic Lead Exposure is Epidemic in Obligate Scavenger Populations in Eastern North America" 2015 Environment Internationa/ 51-55

Bekker et al Innocent until Proven Guilty

Bekker $\mathrm{F}$ et al Innocent until Proven Guilty (Endangered Wildlife Trust Parkview Undated)

Bildstein "History of Raptor Conservation"

Bildstein KL "A Brief History of Raptor Conservation in North America" in Bildstein KL et al (eds) State of North America's Birds of Prey (Nuttall Ornithological Club and American Ornithologists' Union Washington DC 2008) 5-36

Birkhead, Wimpenny and Montgomerie Ten Thousand Birds

Birkhead T, Wimpenny J and Montgomerie B Ten Thousand Birds. Ornithology since Darwin (Princeton University Press Princeton 2014) 
Bodio An Eternity of Eagles

Bodio SJ An Eternity of Eagles. The Human History of the Most Fascinating Bird in the World (Lyons Press Guilford 2012)

Breining Return of the Eagle

Breining G Return of the Eagle. How America Saved its National Symbol $2^{\text {nd }}$ ed (Lyons Press Guilford 2008)

Burnham "Raptors and People"

Burnham WA "Raptors and People" in Newton I (ed) Birds of Prey (Merehurst Press London 1990) 170-188

Burns and Kidd "Administrative Law"

Burns $Y$ and Kidd $M$ "Administrative Law and Implementation of Environmental Law" in Strydom HA and King ND (eds) Environmental Management in South Africa $2^{\text {nd }}$ ed (Juta Cape Town 2009) 222-268

Clark and Schmitt Raptors of Europe

Clark WS and Schmitt NJ A Field Guide to Raptors of Europe, the Middle East, and North Africa (Oxford University Press Oxford 1999)

Committee on Scientific Issues in the Endangered Species Act et al Science and the Endangered Species Act

Committee on Scientific Issues in the Endangered Species Act et al Science and the Endangered Species Act (National Academy Press Washington DC 1995)

Davies 1999 Journal of Raptor Research

Davies RAG "Extent, Cost and Control of Livestock Predation by Eagles with a Case Study on Black Eagles (Aquila verreauxi) in the Karoo" 1999 (1) Journal of Raptor Research 67-72

Debus Birds of Prey of Australia

Debus S Birds of Prey of Australia $2^{\text {nd }}$ ed (CSIRO Collingwood 2012) 
Del Hoyo and Collar Birds of the World

Del Hoyo J and Collar NJ HBW and BirdLife International Illustrated Checklist of the Birds of the World (Lynx Edicions Barcelona 2014)

Del Hoyo, Elliot and Sargatal Handbook of the Birds of the World

Del Hoyo J, Elliot A and Sargatal J (eds) Handbook of the Birds of the World Vol 2 (Lynx Edicions Barcelona 1994)

De Meo 1995 Hastings Const LQ

De Meo AM "Access to Eagles and Eagle Parts: Environmental Protection v Native American Free Exercise of Religion" 1995 Hastings Constitutional Law Quarterly 771-813

Dickinson and Remsen Checklist

Dickinson EC and Remsen JV The Howard and Moore Complete Checklist of the Birds of the World Vol $14^{\text {th }}$ ed (Aves Press Eastbourne 2013)

Doub Endangered Species Act

Doub JP The Endangered Species Act (CRC Press Boca Raton 2013)

Dunne, Sibley and Sutton Hawks in Flight

Dunne P, Sibley D and Sutton C Hawks in Flight (Houghton Mifflin Boston 1988)

Ferguson-Lees and Christie Raptors of the World (2001)

Ferguson-Lees $\mathrm{J}$ and Christie DA Raptors of the World (Christopher Helm London 2001)

Ferguson-Lees and Christie Raptors of the World (2005)

Ferguson-Lees J and Christie DA Raptors of the World (Christopher Helm London 2005)

Glazewski Environmental Law

Glazewski J (ed) Environmental Law in South Africa (LexisNexis Durban 2013) 
Gordon Golden Eagle

Gordon S The Golden Eagle. King of Birds (Citadel Press New York 1955)

Hockey, Dean and Ryan Roberts Birds of Southern Africa

Hockey PAR, Dean WRJ and Ryan PG (eds) Roberts Birds of Southern Africa $7^{\text {th }}$ ed (John Voelcker Bird Book Fund Cape Town 2005)

Iraola 2005 Albany $L$ Rev

Iraola R "The Bald and Golden Eagle Protection Act" 2005 Albany L Rev 973996

Johnsgard Hawks, Eagles and Falcons of North America

Johnsgard PA Hawks, Eagles and Falcons of North America. Biology and Natural History (Smithsonian Institution Press Washington 1990)

Katzner and Tingay "Eagle Diversity, Ecology and Conservation"

Katzner TE and Tingay RE "Eagle Diversity, Ecology and Conservation" in Tingay RE and Katzner TE (eds) The Eagle Watchers (Cornell University Press Ithaca 2010) 1-25

Kemp and Kemp Birds of Prey

Kemp A and Kemp M Birds of Prey of Africa and its Islands (Struik Cape Town 2006)

Kemp "What is a Raptor?"

Kemp A "What is a Raptor?" in Newton I (ed) Birds of Prey (Merehurst London 1990) $14-31$

Kidd Environmental Law

Kidd M Environmental Law $2^{\text {nd }}$ ed (Juta Cape Town 2011)

Knobel 2013 PER/PELJ

Knobel JC "The Conservation Status of Eagles in South African Law" 2013 (16)4 PER/PELJ 160-230 
Knobel 2015 De Jure

Knobel JC "The Conservation Status of the Wedge-tailed Eagle in Australian Law and Thoughts on the Value of Early Legal Intervention in the Conservation of a Species" 2015 De Jure 293-311

Kovacs 2013 Loy LA L Rev

Kovacs KE "Eagles, Indian Tribes, and the Free Exercise of Religion" 2013 Loy $L A L \operatorname{Rev} 53-116$

Laycock Autumn of the Eagle

Laycock G Autumn of the Eagle (Charles Scribner's Sons New York 1973)

Liebesman and Petersen Endangered Species Deskbook

Liebesman LR and Petersen R Endangered Species Deskbook $2^{\text {nd }}$ ed (Environmental Law Institute Washington DC 2010)

McKechnie 2015 African Birdlife

McKechnie A "Stomach This. Vultures and Their Putrid Diet" 2015 (3) African Birdlife 13

Naoroji Birds of Prey of the Indian Subcontinent

Naoroji R Birds of Prey of the Indian Subcontinent (OM Books International New Delhi 2011)

Newman Kruger National Park

Newman K Birds of Southern Africa 1: Kruger National Park (MacMillan Johannesburg 1980)

Newton Population Ecology

Newton I Population Ecology of Raptors (T \& AD Poyser London 1979)

Noecker "Revisions"

Noecker RJ "Endangered Species List Revisions: a Summary of Delisting and Downlisting" in Foreman P (ed) Endangered Species: Issues and Analyses (Nova Science Publishers New York 2002) 121-147 
Oberprieler Raptor Guide of Southern Africa

Oberprieler U The Raptor Guide of Southern Africa (Ulrich Ecoventures Pretoria 2012)

Palmer "Golden Eagle"

Palmer RS "Golden Eagle" in Palmer RS (ed) Handbook of North American Birds Vol 5 (Yale University Press New Haven 1988) 180-231

Perkins 2000 Envtl L

Perkins M "The Federal Indian Trust Doctrine and the Bald and Golden Eagle Protection Act: Could Application of the Doctrine Alter the Outcome in US $v$ Hugs?" 2000 Envtl L 701-727

Porter et al Flight Identification of European Raptors

Porter RF et al Flight Identification of European Raptors (T \& AD Poyser Berkhamstead 1986)

Ruhl "Listing Endangered and Threatened Species"

Ruhl JB "Listing Endangered and Threatened Species" in Baur DC and Irvin WMR Endangered Species Act. Law, Policy and Perspectives (American Bar Association Chicago 2010) 16-39

Scott, Goble and Davis "Introduction"

Scott JM, Goble DD and Davis FW "Introduction" in Goble DD, Scott JM and Davis FW (eds) The Endangered Species Act at Thirty Vol 1 (Island Press Washington DC 2006) 3-15

Snyman Criminal Law

Snyman CR Criminal Law $6^{\text {th }}$ ed (LexisNexis Durban 2014)

Steyn Birds of Prey of Southern Africa

Steyn P Birds of Prey of Southern Africa (David Philip Cape Town 1982) 
Tarboton "Foreword"

Tarboton W "Foreword" in Malan G (ed) Raptor Survey and Monitoring (Briza Pretoria 2009) iv

Thelander and Smallwood "Altamont Pass"

Thelander CG and Smallwood KS "The Altamont Pass Wind Resource Area's Effects on Birds: A Case History" in De Lucas M, Janss GFE and Ferrer M (eds) Birds and Wind Farms: Risk Assessment and Mitigation (Servicios Informativos Ambientales/Quercus Madrid 2007) 25-46

Tucker Return of the Bald Eagle

Tucker P The Return of the Bald Eagle (Stackpole Books Mechanicsburg 1994)

Watson Golden Eagle

Watson J The Golden Eagle $2^{\text {nd }}$ ed (T \& AD Poyser London 2010)

Wheeler Raptors of Eastern North America

Wheeler BK Raptors of Eastern North America (Princeton University Press Princeton 2003)

Wheeler Raptors of Western North America

Wheeler BK Raptors of Western North America (Princeton University Press Princeton 2003)

Worthen 2005 U Colo L Rev

Worthen $\mathrm{KJ}$ "Eagle Feathers and Equality: Lessons on Religious Exceptions from the Native American Experience" 2005 U Colo L Rev 989-1020

\section{Case law}

McAllen Grace Brethren Church v Salazar (5th Cir 2014) Unreported Case No 1340326 of 20 August 2014

United States v Friday 525 F 3d 938 (10th Cir 2008)

United States v Fryberg 622 F 2d 1010 (9th Cir 1980) 
United States v Hardman 297 F 3d 1116 (10th Cir 2002)

United States v Wilgus 638 F 3d 1274 (10th Cir 2011)

\section{Legislation}

\section{Australia}

Environment Protection and Biodiversity Conservation Act 1999 (Cth)

Environment Protection and Biodiversity Conservation Regulations 2000 (Cth)

Wildlife Conservation Act 1950 (Western Australia)

\section{European Union}

Council Directive 2009/147/EC (30 November 2009) on the Conservation of Wild Birds(Codified Version) [2010] OJ L 20/7 (Birds Directive)

\section{South Africa}

Bophuthatswana Nature Conservation Act3 of 1973

Kwa-Zulu Nature Conservation Act29 of 1992

Limpopo Environmental Management Act 7 of 2003

Mpumalanga Nature Conservation Act 10 of 1998

National Environmental Management: Biodiversity Act 10 of 2004

Nature and Environmental Conservation Ordinance 19 of 1974

Nature Conservation Ordinance 8 of 1969 (Free State)

Nature Conservation Ordinance 12 of 1983

Nature Conservation Ordinance 15 of 1974

Northern Cape Nature Conservation Act 9 of 2009

Threatened or Protected Species Regulations, 2007 (TOPS Regulations)

\section{United States of America}

Bald and Golden Eagle Protection Act of 1940 (16 USC 668-668d)

Bald Eagle Protection Act of 1940 (16 USC 668)

Criminal Fines Improvement Act of 1987 (Pub L 100-185, 101 Stat 1279, 18 USC 3571)

Endangered Species Act of 1973 (16 USC 1531-1544)

Endangered Species Preservation Act of 1966 (Pub law 89-699) 
Joint Resolution: To Provide Protection for the Golden Eagle (Pub L 87-884, Oct 24 1962, 76 Stat 12466)

Migratory Bird Treaty Act of 1994 (16 USC 703-712)

\section{Government publications}

\section{South Africa}

TOPS Regulations (GN R152 in GG 29657 of 23 February 2007)

Lists of Critically Endangered, Endangered, Vulnerable and Protected Species (GN R151 in GG 29657 of 23 February 2007)

Publication of Lists of Species that are Threatened or Protected, Activities that are Prohibited and Exemption from Restriction (Gen N 389 in GG 36375 of 16 April 2013)

Publication of Lists of Species that are Threatened or Protected, Activities that are Prohibited and Exemption from Restriction (Gen N 256 in GG 38600 of 31 March 2015)

\section{United States of America}

32 FR 4001

$37 F R 13369$

43 FR 6233

60 FR 3600136010

64 FR 5046750473

$72 F R 37346$

\section{International instruments}

Convention for the Protection of Migratory Birds and Game Mammals (1936)

Convention on International Trade in Endangered Species of Wild Fauna and Flora (1973) (CITES)

Convention on the Conservation of European Widlife and Natural Habitats (1979) (Bern Convention)

Convention on the Conservation of Migratory Species of Wild Animals (1979) (Bonn Convention) 
Memorandum of Understanding on Migratory Birds of Prey in Africa and Eurasia (2008) (Raptors Mol)

\section{Internet sources}

African Raptors 2011 http://www.africanraptors.org/an-interview-with-andre-bothaabout-raptor-conservation-in-south-africa/

African Raptors 2011 An Interview with André Botha about Raptor Conservation in South Africa http://www.africanraptors.org/an-interview-withandre-botha-about-raptor-conservation-in-south-africa/ accessed 18 September 2015

BirdLife International 2015 http://www.birdlife.org/datazone/speciesfactsheet. php?id=3365

BirdLife International 2015 Species Factsheet: Haliaeetus leucocephalus http://www.birdlife.org/datazone/speciesfactsheet.php?id=3365 accessed 13 March 2015

BirdLife International 2015 http://www.birdlife.org/datazone/speciesfactsheet .php?id=3537

BirdLife International 2015 Species Factsheet: Aquila chrysaetos http://www.birdlife.org/datazone/speciesfactsheet.php?id=3537 accessed 13 March 2015

BirdLife International 2015 http://www.birdlife.org/datazone/speciesfactsheet.php ?id $=3540$

BirdLife International 2015 Species Factsheet: Hieraaetus wahlbergi http://www.birdlife.org/datazone/speciesfactsheet.php?id=3540 accessed 13 March 2015

CMS 2014 www.cms.int

Convention on International Trade in Endangered Species of Wild Fauna and Flora 2014 Convention on the Conservation of Migratory Species of Wild Animals http://www.cms.int accessed 20 March 2015 
EPA 2015 http://www2.epa.gov/aboutepa

United States Environmental Protection Agency 2015 About EPA http://www2.epa.gov/aboutepa accessed 20 March 2015

EPA 2014 http://www2.epa.gov/aboutepa/ddt-ban-takes-effect

United States Environmental Protection Agency 2014 DDT Ban Takes Effect [EPA press release - December 31, 1972] http://www2.epa.gov/ aboutepa/ddt-ban-takes-effect accessed 13 March 2015

EPA 2014 http://www2.epa.gov/aboutepa/ddt-regulatory-history-brief-survey-1975 United States Environmental Protection Agency 2014 DDT Regulatory History: A Brief Survey (To 1975) http://www2.epa.gov/aboutepa/ddt-regulatoryhistory-brief-survey-1975 accessed 13 March 2015

EWT $2012 \quad$ https://www.ewt.org.za/eBooks/booklets/Eagles\%20and\%20 Farmers\%20booklet.pdf

Endangered Wildlife Trust 2012 Eagles and Farmers https://www.ewt.org.za/eBooks/booklets/Eagles\%20and\%20Farmers\%20boo klet.pdf accessed 18 September 2015

EWT 2014 https://www.ewt.org.za/BOP/platberg.html

Endangered Wildlife Trust 2014 Birds of Prey Programme Platberg Karoo Raptor Project https://www.ewt.org.za/BOP/platberg.html accessed 18 September 2015

EWT 2014 https://www.ewt.org.za/conreports/2014/book.swf

Endangered Wildlife Trust 2014 Conservation in Action Integrated Report 2013-2014 https://www.ewt.org.za/conreports/2014/book.swf accessed 18 September 2015

Global Raptor Information Network 2012 http://globalraptors.org/ grin/SpeciesExtended.asp?specID=8162\&catID=2007\&childID=149\&sSpecies Name $=$ Aquila chrysaetos 
Global Raptor Information Network 2012 Aquila chrysaetos Additional Details on Conservation http://globalraptors.org/grin/SpeciesExtended.asp?specID= 8162\&catID $=2007 \&$ childID $=149 \&$ sSpecies $N a m e=$ Aquila chrysaetos accessed 20 March 2015

Global Raptor Information Network 2015 http://www.globalraptors.org/ grin/SpeciesResults.asp?specID $=8162$

Global Raptor Information Network 2015 Species Account: Golden Eagle Aquila chrysaetos http://www.globalraptors.org/grin/SpeciesResults.asp? specID=8162 accessed 12 March 2015

Global Raptor Information Network 2015 http://www.globalraptors.org/grin/ SpeciesResults. asp?specID $=8270$

Global Raptor Information Network 2015 Species Account: Bald Eagle Haliaeetus leucocephalus http://www.globalraptors.org/grin/SpeciesResults. asp?specID=8270 accessed 12 March 2015

International Association for Falconry and Conservation of Birds of Prey 2013 http://www.iaf.org/Legislation.php

International Association for Falconry and Conservation of Birds of Prey 2013 Legislation http://www.iaf.org/Legislation.php accessed 30 March 2015

IUCN 2014 http://www.iucnredlist.org/details/full/22695144/0

International Union for the Conservation of Nature and Natural Resources 2014 The IUCN Red List of Threatened Species: Haliaeetus leucocephalus http://www.iucnredlist.org/details/full/22695144/0 accessed 13 March 2015

IUCN 2014 http://www.iucnredlist.org/details/full/22696060/0

International Union for the Conservation of Nature and Natural Resources 2014 The IUCN Red List of Threatened Species: Aquila chrysaetos http://www.iucnredlist.org/details/full/22696060/0 accessed 13 March 2015 
IUCN 2015 http://www.iucnredlist.org/details/full/22696072/0

International Union for the Conservation of Nature and Natural Resources 2015 The IUCN Red List of Threatened Species: Hieraaetus wahlbergi http://www.iucnredlist.org/details/full/22696072/0 accessed 20 March 2015

Lombard Date Unknown http://www.andersonafrica.co.za/pamphlets/Falconry.pdf Lombard A Date Unknown Falconry in Southern Africa http://www.andersonafrica.co.za/pamphlets/Falconry.pdf accessed 30 March 2015

Roggenbuck et al 2014 http://www.nature.com/ncomms/2014/141125/ ncomms6498/full/ncomms6498.html

Roggenbuck M et al 2014 The Microbiome of New World Vultures http://www.nature.com/ncomms/2014/141125/ncomms6498/full/ncomms649 8.html accessed 13 March 2015

UNEP/CMS Secretariat 2014 http://www.cms.int/raptors/en/legalinstrument/birdsprey-raptors

UNEP/CMS Secretariat 2014 Raptors http://www.cms.int/raptors/en/ legalinstrument/birds-prey-raptors accessed 20 March 2015

US Fish and Wildlife Service 2011 http://www.fws.gov/endangered/esalibrary/pdf/history_ESA.pdf

US Fish and Wildlife Service 2011 A History of the Endangered Species Act of 1973 http://www.fws.gov/endangered/esa-library/pdf/history_ESA.pdf accessed 12 March 2015

US Fish and Wildlife Service 2011 http://www.fws.gov/ migratorybirds/NewReportsPublications/FactSheets/Golden_Eagle_Status_Fact _Sheet[1].pdf

US Fish and Wildlife Service 2011 Golden Eagles. Status Factsheet http://www.fws.gov/migratorybirds/NewReportsPublications/FactSheets/Golde n_Eagle_Status_Fact_Sheet[1].pdf accessed 20 March 2015 
US Fish and Wildlife Service 2013 http://www.fws.gov/endangered/lawspolicies/timeline.html

US Fish and Wildlife Service 2013 Endangered Species Act Timeline http://www.fws.gov/endangered/laws-policies/timeline.html accessed 12 March 2015

US Fish and Wildlife Service 2013 http://www.fws.gov/midwest/ eagle/recovery/qandas.html

US Fish and Wildlife Service 2013 Bald Eagle http://www.fws.gov/midwest/eagle/recovery/qandas.html accessed 20 March 2015

US Fish and Wildlife Service 2015 http://www.fws.gov/eaglerepository/

US Fish and Wildlife Service 2015 National Eagle Repository http://www.fws.gov/eaglerepository/ accessed 12 March 2015

US Fish and Wildlife Service 2015 http://www.fws.gov/index.html

US Fish and Wildlife Service 2015 Conserving the Nature of America http://www.fws.gov/index.html accessed 20 March 2015

Wisch 2014 https://www.animallaw.info/article/detailed-discussion-bald-and-goldeneagle-protection-act

Wisch RF 2014 Detailed Discussion of the Bald and Golden Eagle Protection Act https://www.animallaw.info/article/detailed-discussion-bald-and-goldeneagle-protection-act accessed 12 March 2015

\section{LIST OF ABBREVIATIONS}

Albany L Rev

CITES

CMS

Cth
Albany Law Review

Convention on International Trade in Endangered Species of Wild Fauna and Flora

Convention on the Conservation of Migratory Species of Wild Animals

Commonwealth (as used pertaining to Australian 
legislation)

DDT

Dichlor-diphenyl-trichlorethane

Envtl L

Environmental Law

EPA

United States Environmental Protection Agency

EWT

Endangered Wildlife Trust

FR

Federal Register

Hastings Const LQ

Hastings Constitutional Law Quarterly

IUCN

International Union for Conservation of Nature

Loy LA L Rev

Loyola of Los Angeles Law Review

NEMBA

National Environmental Management: Biodiversity Act

PER/PEL

Potchefstroomse Elektroniese Regsblad / Potchefstroom

Electronic Law Journal

Raptors MOU

TOPS

Memorandum of Understanding on the Conservation of Migratory Birds of Prey in Africa and Eurasia

UNEP

Threatened or Protected Species

U Colo L Rev

United Nations Environment Programme

University of Colorado Law Review 